\title{
Genetics of Antiphospholipid Syndrome
}

\section{Veysel Sabri Hancer*}

Istanbul Bilim University, Faculty of Medicine, Department of Medical Biology and Genetics, Istanbul, Turkey

\begin{abstract}
Antiphospholipid syndrome (APS) is defined as recurrent arterial and/or venous thrombosis and obstetric complications in the presence of antiphospholipid antibodies (aPL). The possibility of a genetic predisposition to develop antiphospholipid syndrome (APS) and to produce anticardiolipin antibodies and lupus anticoagulant has been examined by family studies and population studies. Similar to many other polygenic autoimmune diseases, human leukocyte antigen associations have been reported. The genetics of $\beta 2$ - glycoprotein I, one of the most representative target antigens of aPL, has been extensively studied. Additional genetic risk factors for the development of thrombosis in patients with aPL have also been discussed. Although the mechanisms and pathophysiology of thrombosis in APS are highly heterogeneous and multifactorial, different genes seem to be involved.
\end{abstract}

The term "antiphospholipid syndrome" has been proposed to describe the association of arterial and venous thrombosis, recurrent fetal loss, and immune thrombocytopenia with a spectrum of autoantibodies directed against cellular phospholipid components. Because of the antigen spesifity of antiphospholipid antibodies (aPL) and the pathophysiology of thrombosis in antiphospholipid syndrome (APS) are heterogeneous and multifactorial, a single scenario can not explain the mechanisms of thrombophilia or pregnancy morbidity in pateints. Investigation of the clinical epidemiology of APS is in its early stages. During the past 20 years, studies of aPL and APS have been made in many countries [1-11]. aPL appear to occur in all populations studied, with some variations noted in their frequency and in the clinical complications $[1,9,10,12,13]$. Environmental and genetic factors contribute to ethnic variation and susceptibility to APS and thus interethnic differences in disease patterns may be due to environmental or genetic factors, or both $[1,14]$. A genetic basis for aPL antibodies was suggested for the first time when a familial clustering of chronic false-positive syphilis test individuals were detected [15]. The first description about aPL showed two pairs of siblings with lupus anticoagulant (LA) [16]. Subsequently, primary APS was described [17] and Cevallos et al. [18] reported the development of primary APS in one woman whose identical twin sister was an asymptomatic carrier of aPL. Relatives of patients with sistemic lupus erythematosus (SLE) or primary APS had a higher incidence of anticardiolipin antibodies $(\mathrm{aCL})[19,20]$ suggesting that a genetic factor may relevant with aPL. Mackie et al. [21] reported three families having more than one member with LA and called familial lupus anticoagulants. The identification of several pedigrees with an increased frequency of aPL antibodies and the associated clinical manifestations further support the familial form of APS. In one of these studies, a large kindred in which nine individuals had aPL antibodies was described. Associated clinical manifestations included stroke, deep venous thrombosis and recurrent abortions [22]. In another study, clinical and laboratory abnormalities in seven families with more than one affected person with segragation analysis, Goel et al suggested that a susceptibility gene is inherited in an autosomal dominant patern [23]. Segregation studies rejected environment and autosomal recessive models, and the data were fitted best by a dominant or codominant model. However, linkage analysis showed independent segregation of APS and several candidate genes.

\section{Genes associated with antiphospholipid syndrome}

Human Leucocyte Antigen (HLA) Studies: HLA class II antigens (DR, DP, DQ) loci is located on chromosome 6 and these molecules are highly polymorphic. Therefore, HLA class II polymorphisms have been implicated in association with autoimmune responses, in particular antigen specific immune responses. In a study of 13 patients with the primary APS, HLA-DR4 and DRw53 were more frequently found, but no correction was made for multiple comparisons [24]. The data confirmed in a population from Spain [25] and Canada [7]. Studies of HLA alleles in patients with conventianal aCL showed increased frequencies of HLA DR4 [26] or DR7 [25,27] in SLE population. DR7 was also increased in Mexican patients with aCL [28]. Hartung et al. [29] reported that HLA-DR4 and DR7 were increased in aCL positive patients in European SLE populations and aCL were significantly associated with DRw53. In a study of 20 patients with SLE and LA, an association with HLA-DQw7 (HLA DQB1 ${ }^{\star} 0301$ ) linked to HLADR4 and/or -DR5 haplotypes was found in $70 \%$ of patients and was significantly increased compared with 139 matched control individuals $(\mathrm{p}=0.002)$ [30]. According to this study, several HLA-DQB1 alleles shared a common aminoacid sequence (positions 71-77) in the third hypervariable region of the outermost domain. This HLA-DQB1 sequence, called TRAELDT, is distinct from those found in the HLADQB1 alleles of HLADQw2, -DQw4 and -DQw5 and, as such, may represent an autoantibody. However, LA may comprise heterogeneous autoantibodies, such as anti $\beta 2 \mathrm{GPI}$, antiprothrombin and so forth, and in these studies investigators did not discriminate these heterogeneous antibodies. It is clear that HLA class II gene should not be considered to be a single genetic risk factor for APS because the antigen specificity of aPL and clinical manifestations are highly heterogeneous.

及2-Glycoprotein I: $\beta 2$-glycoprotein I or apolipoprotein $\mathrm{H}$ is a single chain glycoprotein with a molecular weight of approximately $50 \mathrm{kD}$ and 326 amino acid residues. A member of the shortconsensus repeat protein family, beta2-GPI is characterized by five 'sushi-

*Corresponding author: Asst.Prof.Dr.Veysel Sabri Hancer, Istanbul Bilim University, Faculty of Medicine, Department of Medical Biology and Genetics, Buyukdere Cad No:120 Esentepe, 34394, Istanbul, Turkey E-mail: vshancer@ yahoo.com

Received August 18, 2011; Accepted August 25, 2011; Published September 30, 2011

Citation: Hancer VS (2011) Genetics of Antiphospholipid Syndrome. Human Genet Embryol 1:e103. doi:10.4172/2161-0436.1000e103

Copyright: (c) 2011 Hancer VS. This is an open-access article distributed unde the terms of the Creative Commons Attribution License, which permits unrestricted use, distribution, and reproduction in any medium, provided the original author and source are credited. 
domains'. The fifth sushi-domain contains the binding site to phospholipid, and it attaches to activated cellular surfaces [31]. $\beta 2$ GPI binds to various negatively charged phospholipids and inhibits intrinsic blood coagulation pathway [32], prothrombinase activity of human platelets [33], and adenosine diphosphate (ADP) dependent platelet aggregation [34]. When $\beta 2$-GPI binds to negatively charged phospholipids, it behaves as a cofactor for aCL binding and interacts with coagulation reactions. Several studies have shown the significance of anti- $\beta 2$-GPI as an alternative enzyme linked immunosorbent assay (ELISA) with higher specificity than the conventional aCL ELISA. Moreover, many studies suggest that the presence of anti- $\beta 2-\mathrm{GPI}$ is closely associated with clinical manifestations of APS and anti- $\beta 2$ GPI play important roles in pathogenesis of APS such as platelet and endothelial cell activation and induction of tissue factor. Human $\beta 2$-GPI gene is located on chromosome 17 and so far four common single nucleotide polymorphisms in protein coding region have been identified [35,36]. Eightyeight Ser/Asn, $247 \mathrm{Val} / \mathrm{Leu}, 306 \mathrm{Cys} / \mathrm{Gly}$, and $316 \mathrm{Trp} /$ Ser polymorphisms are located in exon $3,7,7$, and 8 of $\beta 2$ GPI gene, respectively. Val/Leu polymorphism at codon 247 has been extensively studied among these polymorphisms. Two hundred fortyseven $\mathrm{Val} / \mathrm{Leu}$ polymorphism is located between the phospholipid binding site in fifth domain and fourth domain of $\beta 2$-GPI, one of the potential epitopes recognized anti- $\beta 2$-GPI from patients with APS. $306 \mathrm{Cys} / \mathrm{Gly}$, and $316 \mathrm{Trp} / \mathrm{Ser}$ polymorphisms may affect the structure of phospholipid binding site of domain 5 of $\beta 2$-GPI [37]. 247 Val/Leu polymorphism can affect the conformational change of $\beta 2$-GPI and the exposure of the epitopes for aCL. Hirose et al. [38] found that the 247 Val allele was more frequently detected in Asian patients with APS than in matched normal individuals. Furthermore, it reported an association between the Val247Val homozygous genotype and the presence of anti- $\beta 2$ GPI antibodies only among Asian patients with APS. The authors found no evidence of an increased risk of thrombosis in this Asian population. Atsumi et al. [39] analyzed $247 \mathrm{Val} / \mathrm{Leu}$ polymorphism in a cohort of 88 British APS patients and found $247 \mathrm{Val}$ was correlated with anti- $\beta 2$-GPI production in patients with primary APS, and $247 \mathrm{Val}$ may be important for $\beta 2$-GPI antigenicity. Prieto et al. [40] suggested that Val/Val genotype at codon 247 played a role in the generation of anti- $\beta 2$-GPI and in the expression of arterial thrombosis in Mexican primary APS. On the other hand, Camilleri et al. [41] found no association $247 \mathrm{Val} /$ Leu polymorphism and the presence of anti$\beta 2$-GPI in the white population. There have been several reports of two common polymorphisms (306 Cys/Gly and $316 \mathrm{Trp} / \mathrm{Ser}$ ) located in the fifth domain of $\beta 2$-GPI. These two polymorphisms in the fifth domain affect the binding of $\beta 2$-GPI to anionic phospholipids [42]. Kamboh et al. [43] found 316 Ser allele was protective against the production of aPL in SLE population. On the other hand, Gushiken FC et al. [44] found no significant correlation between these polymorphisms and the presence of aPL in 143 SLE and/or APS patients. Moreover, their results suggested that $316 \mathrm{Trp} / \mathrm{Ser}$ polymorphism might predispose to thrombosis as an independent risk factor in patients with SLE.

\section{Additional genetic risk factors}

All patients with aPL do not develop the clinical findings of APS. This suggests that additional genetic factors may be involved in the development of the clinical characteristics of APS. Polymorphisms in genes involved in thrombus formation have been examined. Factor $\mathrm{V}$ Leiden mutation that results 506Arg/Gln substitution is the most common factor for venous thrombosis. According to Fijnheer et al. [45]. Factor V Leiden was independent risk factor venous thrombosis, but not for arterial thrombosis in patients with SLE. Montaruli et al. [46] analyzed 60 patients with aPL and found the incidence of Factor $\mathrm{V}$ mutation was significantly elevated in patients with venous thrombosis. Pablos et al. [47] examined 75 patients with primary APS and 83 patients with SLE and aPL with or without thrombosis and found Factor V Leiden mutation was not significantly associated with vein thrombosis in patients with aPL. Brouwer et al. (48) dtermined the contribution of thrombophilic disorders including Factor $\mathrm{V}$ Leiden and the prothrombin G20210A mutation, alone or in various combinations with aPL, to the risk of thrombosis in patients with SLE. aPL, Factor V Leiden, and prothrombin G20210A mutation were reported as risk factors for venous thrombosis and these mutations potentiated the risk for venous thrombosis when these mutations were combined with aPL. In contrast with aPL, thrombophilic disorders did not influence the risk for arterial thrombosis. In another study [49] ninetyfour APS patients with documented thrombosis, 40 patients with persistent antiphospholipid antibody (aPLA) positivity but without thrombosis, and healthy controls were screened. They found that inherited protein $\mathrm{C}$, protein $\mathrm{S}$, and antithrombin deficiencies were rare in APS patients. The presence of factor V Leiden mutation was significantly higher in APS patients with thrombosis compared to healthy controls ( $p=0.0043$ ). The prevalence of prothrombin G20210A mutation, however was not significantly increased in APS patients with thrombosis compared to patients without thrombosis $(p=0.67)$. The presence of factor $V$ Leiden mutation may define a small but important subgroup of patients who had high risk of both venous and arterial thrombosis. Known thrombophilic risk factors however, may influence the development of thrombotic complications in approximately $10 \%$ of APS patients. Protrombin G20210A mutation is a risk factor for arterial and venous thrombosis [50]. This mutation was found to be rare in APS and several studies have not shown association between thrombosis in APS and this mutation [51-53]. APS patients with MTHFR 677TT genotype had a lower mean age at first thrombotic events and an increased average number of thrombotic events per person than APS patients with 677 CC or CT $[54,55]$. Fijnhaer et al reported that raised levels of homocysteine in SLE patients with arterial thrombosis but no MTHFR $677 \mathrm{C} / \mathrm{T}$ association with raised levels of homocysteine [56]. Tassies et al. [57] reported a higher frequency of the $4 \mathrm{G}$ allele in APS patients with arterial thrombosis than those without arterial thrombosis. On the other hand, Yasuda et al. [58] reported that polymorphism of PAI-1 gene did not significantly influence the risk for arterial thrombosis, venous thrombosis, or pregnancy morbidity in 77 Japanese and 82 British patients with aPL. A meta-analysis, Tsantes et al. [59] investigated the association between the PAI1 4G/5G polymorphism and the risk of venous thromboembolism (VTE) in 18 papers. According to this study, the $4 \mathrm{G}$ allele appears to increase the risk of venous thrombosis, particularly in subjects with other genetic thrombophilic defects. Diz-Kucukkaya et al. [60] found that factor XIII Val34Leu polymorphism decreased the risk of both arterial and venous thrombosis. Nevertheless, the results showed that the Leu34 allele had no protective effect in the development of thrombosis in patients with APS. On the contrary, de la Red et al. [61] found that this polymorphism was associated with a higher risk of thrombosis in patients with the presence of both aPL antibodies and high fibrinogen levels. They found no significant differences in Leu34 allele frequencies between primary APS, APS/SLE, SLE-aPL and asymptomatic-aPL patients, or between patients with and without thrombosis. In this study, the Leu34 allele seemed to have a protective effect on the development of thrombosis in patients with aPL antibodies, but only in those patients with high plasma fibrinogen values. 


\section{Conclusions}

The elucidation of pathogenetic mechanism of APS may help to identify patients who are at high risk for thrombosis, and may improve management of the patients. Genetics of aPL and APS has been extensively examined in past 20 years. However, it has been difficult to determine genetic factors for aPL and APS because of the heterogeneity in the antigen specificity and in the pathogenesis of clinical manifestations related to APS. Several genetic factors may be involved in its pathophysiology, ethnic factors are also important. Genome-wide linkage analysis and larger cohort case-control association studies, as well as multicenter international collaborations would be useful for a beter understanding of the genetic predisposition to develop APS.

\section{References}

1. Wilson WA (2000) Ethnicity and APS. J Autoimmun 15: 153-155.

2. Harris EN, Gharavi AE, Boey ML, Patel BM, Mackworth-Young CG, et al. (1983) Anticardiolipin antibodies: detection by radioimmunoassay and association with thrombosis in systemic lupus erythematosus. Lancet 2: 1211-1214.

3. Wilson WA, Perez MC, Michalski JP, Armatis PE (1988) Cardiolipin antibodies and null alleles of $\mathrm{C} 4$ in black Americans with systemic lupus erythematosus. $\mathrm{J}$ Rheumatol 15: 1768-1772.

4. Jones HW, Ireland R, Senaldi G, Wang F, Khamashta M, et al. (1991) Anticardiolipin antibodies in patients from Malaysia with systemic lupus erythematosus. Ann Rheum Dis 50: 173-175.

5. Molina JF, Molina J, Garcia C, Gharavi AE, Wilson WA, et al. (1997) Ethnic differences in the clinical expression of systemic lupus erythematosus: a comparative study between African-Americans and Latin Americans. Lupus 6 : 63-67.

6. Font J, Lopez-Soto A, Cervera R, Balasch J, Pallares L, et al. (1991) The 'primary' antiphospholipid syndrome: antiphospholipid antibody pattern and clinical features of a series of 23 patients. Autoimmunity 9: 69-75.

7. Goldstein R, Moulds JM, Smith CD, Sengar DP (1996) MHC studies of the primary antiphospholipid antibody syndrome and of antiphospholipid antibodies in systemic lupus erythematosus. J Rheumatol 23: 1173-1179.

8. Saluja S, Kumar A, Khamashta M, Hughes GR, Malaviya AN (1990) Prevalence and clinical associations of anticardiolipin antibodies in patients with systemic lupus erythematosus in India. Indian J Med Res 92: 224-227.

9. Malaviya AN, Chandrasekaran AN, Kumar A, Shamar PN. Systemic lupus erythematosus in India. Lupus 1997 6: 690-700.

10. Abu-Shakra M, Gladman DD, Urowitz MB, Farewell V (1995) Anticardiolipin antibodies in systemic lupus erythematosus: clinical and laboratory correlations. Am J Med 99: 624-628.

11. Gourley IS, McMillan SA, Bell AL. (1996) Clinical features associated with a positive anticardiolipin antibody in Irish patients with systemic lupus erythematosus. Clin Rheumatol 15: 457-460

12. Cucurull E, Espinoza LR, Mendez E, Molina JF, Molina J, et al. (1999) Anticardiolipin and anti-beta2glycoprotein-I antibodies in patients with systemic lupus erythematosus: comparison between Colombians and Spaniards. Lupus 8: $134-141$.

13. Molina JF, Gutierrez-Urena S, Molina J, Uribe O, Richards S, et al. (1997) Variability of anticardiolipin antibody isotype distribution in 3 geographic populations of patients with systemic lupus erythematosus. J Rheumatol 24: 291-296

14. Horita T, Merrill JT (2004) Genetics of antiphospholipid syndrome. Curr Rheumatol Rep 6: 458-462.

15. McGhee-Harvey A, Shulman, LE (1966) Connective tissue disease and the chronic biologic false-positive test for syphilis (BFP reaction). Med Clin North Am 50: 1271-1279.

16. ExnerT, Barber S, Kronenberg H, Rickard KA (1980) Familial association of the lupus anticoagulant. $\mathrm{Br} \mathrm{J}$ Haematol 45: 89-96.
17. Matthey F, Walshe K, Mackie IJ, Machin SJ (1989) Familial ocurrence of the antiphospholipid syndrome. J Clin Pathol 42: 495-497.

18. Cevallos R, Darnige L, Arvieux J, Veyssier P, Gruel Y (1994) Antiphospholipid and anti-beta 2 glycoprotein I antibodies in monozygotic twin sisters. J Rheumatol 21: 1970-1971.

19. Mackworth-Young C, Chan J, Harris N, Walport M, Bernstein R, et al. (1987) High incidence of anticardiolipin antibodies in relatives of patients with systemic lupus erythematosus. J Rheumatol 14: 723-726.

20. Goldberg SN, Conti-Kelly AM, Greco TP (1995) A family study of anticardiolipin antibodies and associated clinical conditions. Am J Med 99: 473-479.

21. Mackie IJ, Colaco CB, Machin SJ (1987) Familial lupus anticoagulants. Br J Haematol 67: 359-363.

22. Ford PM, Brunet D, Lillicrap DP, Ford SE (1990) Premature stroke in a family with lupus anticoagulant and antiphospholipid antibodies. Stroke 21: 66-71.

23. Goel N, Ortel TL, Bali D Anderson JP, Gourley IS, et al. (1999) Familia antiphospholipid antibody syndrome: criteria for disease and evidence for autosomal dominant inheritance. Arthritis Rheum 42: 318- 327.

24. Asherson RA, Doherty DG, Vergani D, Khamashta MA, Hughes GR (1992) Major histocompatibility complex associations with primary antiphospholipid syndrome. Arthritis and Rheumatism 35: 124-125.

25. Camps MT, Cuadrado MJ, Ocon P, Alonso A, Gutierrez A et al. (1995) Association between HLA class II antigens and primary antiphospholipid syndrome from the south of Spain. Lupus 4: 51-55.

26. McHugh NJ, Maddison PJ (1989) HLA-DR antigens and anticardiolipin antibodies in patients with systemic lupus erythematosus Arthritis Rheum 32 1623-1624.

27. Savi M, Ferraccioli GF, Neri TM, Zanelli P, Dall'Aglio PP et al. (1988) HLA$\mathrm{DR}$ antigens and anticardiolipin antibodies in northern Italian systemic lupus erythematosus patients. Arthritis Rheum 31: 1568-1570.

28. Granados J, Vargas-Alarcón G, Andrade F, Melín-Aldana H, Alcocer-Varela J et al. (1996) The role of HLA-DR alleles and complotypes through the ethnic barrier in systemic lupus erythematosus in Mexicans. Lupus 5: 184-189.

29. Hartung K, Coldewey R, Corvetta A, Deicher H, Kalden JR, et al. (1992) MHC gene products and anticardiolipin antibodies in systemic lupus erythematosus results of a multicenter study. SLE Study Group. Autoimmunity 13: 95-99.

30. Arnett FC, Olsen ML, Anderson KL, J D Reveille, et al. (1991) Molecular analysis of major histocompatibility complex alleles associated with the lupus anticoagulant. J Clin Invest 87: 1490-1495.

31. Warm H (1984) Beta-2 glycoprotein I (apolipoprotein H) interactions with phospholipid vesicles. Int J Biochem 16: 511-515.

32. Schousboe I (1985) $\beta_{2}$ : a plasma inhibitor of the contact activation of the intrinsic blood coagulation pathway. Blood 66: 1086-1091.

33. Nimpf J, Bevers EM, Bomans PH, Till U, Wurm H, et al. (1986) Prothrombinase activity of human platelets is inhibitedby b2-glycoprotein-I. Biochim Biophys Acta 884: 142-149.

34. Nimpf J, Wurm H, Kostner GM (1987) Beta 2-glycoprotein-I (apo-H) inhibits the release reaction of human platelets during ADP-induced aggregation. Atherosclerosis 63: 109-114.

35. Steinkasserer A, Dorner C, Wurzner R, Sim RB (1993) Human beta 2-glycoproteinl: molecular analysis of DNA and amino acid polymorphism. Hum Genet 91: 401-402.

36. Sanghera DK, Kristensen T, Hamman RF, Kamboh MI, et al. (1997) Molecular basis of the apolipoprotein $\mathrm{H}$ (beta 2-glycoprotein I) protein polymorphism. Hum Genet 100: 57-2.

37. Kamboh MI, Mehdi H. (1998) Genetics of apolipoprotein H (beta2-glycoprotein I) and anionic phospholipid binding. Lupus 7 Suppl 2: S10-3.

38. Hirose N, Williams R, Alberts AR, Furie RA, Chartash EK, et al. (1999)A role for the polymorphism at position 247 of the beta2-glycoprotein I gene in the generation of anti-beta2-glycoprotein I antibodies in the antiphospholipid syndrome. Arthritis Rheum 42: 1655-1661. 
39. Atsumi T, Tsutsumi A, Amengual O, Khamashta MA, Hughes GR, et al. (1999) Correlation between beta2-glycoprotein I valine/leucine247 polymorphism and anti-beta2-glycoprotein I antibodies in patients with primary antiphospholipid syndrome. Rheumatology 38: 721-723.

40. Prieto GA, Cabral AR, Zapata-Zuñiga M, Simón AJ, Villa AR, et al. (2003) Valine/valine genotype at position 247 of the beta2-glycoprotein I gene in Mexican patients with primary antiphospholipid syndrome: association with anti-beta2-glycoprotein I antibodies. Arthritis Rheum 48: 471-474.

41. Camilleri RS, Mackie IJ, Humphries SE, Machin SJ, Cohen H (2003) Lack of association of beta2-glycoprotein I polymorphisms Val247Leu and Trp316Ser with antiphospholipid antibodies in patients with thrombosis and pregnancy complications. Br J Haematol 120:1066-1072.

42. Sanghera DK, Wagenknecht DR, McIntyre JA, Kamboh MI (1997) Identification of structural mutations in the fifth domain of apolipoprotein $\mathrm{H}$ (beta 2-glycoprotein I) which affect phospholipid binding. Hum Mol Genet 6: 311-316.

43. Kamboh MI, Manzi S, Mehdi H,Fitzgerald S,Sanghera DK, et al. (1999) Genetic variation in apolipoprotein $\mathrm{H}$ (beta2glycoprotein I) affects the occurrence of antiphospholipid antibodies and apolipoprotein $\mathrm{H}$ concentrations in systemic lupus erythematosus. Lupus 8: 742-750.

44. Gushiken FC, Arnett FC, Ahn C, Thiagarajan P (1999) Polymorphism of beta2-glycoprotein I at codons 306 and 316 in patients with systemic lupus erythematosus and antiphospholipid syndrome. Arthritis Rheum 42: 11891193.

45. Fijnheer R, Horbach DA, Donders RC, Vilé H, von Oort E, et al. (1996) Factor $\mathrm{V}$ Leiden, antiphospholipid antibodies and thrombosis in systemic lupus erythematosus. Thromb Haemost 76: 514-517.

46. Montaruli B, Borchiellini A, Tamponi G, Giorda L, Bessone P, et al. (1996) Factor V Arg506-->GIn mutation in patients with antiphospholipid antibodies. Lupus 5: 303-306.

47. Pablos JL, Caliz RA, Carreira PE, Atsumi T, Serrano L et al. (1999) Risk of thrombosis in patients with antiphospholipid antibodies and factor $\mathrm{V}$ Leiden mutation. J Rheumatol 26: 588-590.

48. Brouwer JL, Bijl M, Veeger NJ, Kluin-Nelemans HC, van der Meer J (2004) The contribution of inherited and acquired thrombophilic defects, alone or combined with antiphospholipid antibodies, to venous and arterial thromboembolism in patients with systemic lupus erythematosus. Blood 104: 143-148.

49. Diz-Kucukkaya R, Hancer VS, Artim-Esen B, Pekcelen Y, Inanc M (2010) The prevalence and clinical significance of inherited thrombophilic risk factors in patients with antiphospholipid syndrome. J Thromb Thrombolysis 29: 303-309.

50. Rosendaal FR, Siscovick DS, Schwartz SM, Psaty BM, Raghunathan TE, et al. (1997) A common prothrombin variant (20210 G to A) increases the risk of myocardial infarction in young women. Blood 90: 1747-1450.
51. Bentolila S, Ripoll L, Drouet L, Crassard I, Tournier-Lasserve E, et al. (1997) Lack of association between thrombosis in primary antiphospholipid syndrome and the recently described thrombophilic 3'-untranslated prothrombin gene polymorphism. Thromb Haemost 78: 1415.

52. Bertolaccini ML, Atsumi T, Hunt BJ, Amengual O, Khamashta MA et al. (1998) Prothrombin mutation is not associated with thrombosis in patients with antiphospholipid syndrome. Thromb Haemost 80: 202- 203.

53. Ruiz-Argüelles GJ, Garcés-Eisele J, Ruiz-Delgado GJ, Alarcón-Segovia D. (1999) The G20210A polymorphism in the 3'-untranslated region of the prothrombin gene in Mexican mestizo patients with primary antiphospholipid syndrome. Clin Appl Thromb Hemost 5: 158-160.

54. Ames PR, Tommasino C, D'Andrea G, lannaccone L, Brancaccio V, et al (1998) Thrombophilic genotypes in subjects with idiopathic antiphospholipid antibodies--prevalence and significance. Thromb Haemost 79: 46-49.

55. Ames PR, Margaglione M, Tommasino C, Bossone A, lannaccone L, et al (2001) Impact of plasma homocysteine and prothrombin G20210 A on primary antiphospholipid syndrome. Blood Coagul Fibrinolysis 12: 699-704.

56. Fijnheer R, Roest M, Haas FJ, De Groot PG, Derksen RH (1998) Homocysteine methylenetetrahydrofolate reductase polymorphism, antiphospholipid antibodies, and thromboembolic events in systemic lupus erythematosus: a retrospective cohort study. J Rheumatol 25: 1737-1742.

57. Tàssies D, Espinosa G, Muñoz-Rodríguez FJ, Freire C, Cervera R, et al (Rheum 2000) The 4G/5G polymorphism of the type 1 plasminogen activator inhibitor gene and thrombosis in patients with antiphospholipid syndrome. Arthritis 43: 2349-2358.

58. Yasuda S, Tsutsumi A, Atsumi T, Bertolaccini ML, Ichikawa K, et al. (2002) Gene polymorphisms of tissue plasminogen activator and plasminogen activator inhibitor-1 in patients with antiphospholipid antibodies. J Rheumatol 29: 1192-1197.

59. Tsantes AE, Nikolopoulos GK, Bagos PG, Rapti E, Mantzios G, et al. (2007) Association between the plasminogen activator inhibitor-1 4G/5G polymorphism and venous thrombosis. A meta-analysis. Thromb Haemost 97: 907-913.

60. Diz-Kucukkaya R, Hancer VS, Inanc M, Nalcaci M, Pekcelen Y (2004) Factor XIII Val34Leu polymorphism does not contribute to the prevention of thrombotic complications in patients with antiphospholipid syndrome. Lupus 13: 32-35.

61. de la Red G, Tàssies D, Espinosa G, Monteagudo J, Bové A, et al. (2009) Factor XIII-A subunit Val34Leu polymorphism is associated with the risk of thrombosis in patients with antiphospholipid antibodies and high fibrinogen levels. Thromb Haemost 101: 312-316. 